\title{
PerCursos
}

\section{Velhice: tempo de lembrar? Entre a memória e o esquecimento}

\section{Resumo}

Este artigo se propõe apresentar uma pesquisa realizada a partir de entrevistas de história oral com mulheres idosas. Nelas, estas mulheres privilegiam suas experiências, inicialmente como pequenas agricultoras, emigrantes dos estados de Santa Catarina e Rio Grande do Sul para a região oeste do Paraná, a partir das décadas de 1950 e 1960, e, atualmente, como aposentadas, morando no espaço urbano do município de Marechal Cândido Rondon/PR. Analisamos aqui a história de vida e o relato da experiência da prática da escrita de si (diário) de uma dessas mulheres.

Palavras-chave: Mulheres; Memória; Família; Escrita de si; História oral.

\author{
Gladis Hoerlle \\ Mestra em História pela \\ Universidade Estadual do Oeste \\ do Estado do Paraná - Brasil. \\ gladishoerlle@hotmail.com
}

\section{Para citar este artigo:}

HOERLLE, Gladis. Velhice: tempo de lembrar? Entre a memória e o esquecimento. Revista

PerCursos. Florianópolis, v. 15, n.28, p. 285 - 309. jan./jun. 2014. 


\title{
Old age: time for remember? Between memory and forgetfulness
}

\begin{abstract}
This article presents a research based on oral history interviews with elder women. In their interviews, these women emphasize their experiences as small farmers, who migrated in the 1950 s and 1960 s from Santa Catarina and Rio Grande do Sul states to western Paraná and later as retired women living in Marechal Candido Rondon - PR. In this paper we analyze their life history interviews and the experience of selfwriting (diary) performed by one of them.
\end{abstract}

Keywords: Women. Memories. Family. Selfwriting. Oral history. 


\section{Introdução}

Este artigo tem como propósito refletir acerca de experiências e memórias de mulheres agricultoras aposentadas que vivem no espaço urbano do município de Marechal Cândido Rondon, oeste do Paraná. Com base em narrativas de história oral, analisamos, num trabalho de maior dimensão, as experiências femininas nos processos migratórios para a região e os deslocamentos do campo para a cidade, como lidaram e como lidam com as transformações ocorridas no cotidiano da região e em suas próprias vidas, e como significam a aposentadoria e o processo de envelhecimento vivido na cidade. $^{1}$

A ocupação do atual município a partir de fins dos anos 1940, da qual muitas delas tomaram parte, havia sido baseada em pequenas e médias propriedades rurais, nas quais mulheres e homens se dedicavam à produção agropecuária, inicialmente para a própria família e, mais tarde, para o mercado. ${ }^{2}$

A partir dos anos 1970, o processo de mecanização da agricultura resultou em drásticas alterações na região, como o êxodo rural. A agricultura, então basicamente familiar, passou a sofrer com as consequências da produção em grande escala, principalmente de soja e milho. O mercado do agronegócio, que estava despontando na década de 1970, exigia dos agricultores investimentos na modernização das técnicas de cultivo para incrementar a produção. Esse tipo de agricultura veio acompanhado de consequências socioeconômicas, como a concentração de terras em áreas maiores em mãos de um número menor de agricultores, enriquecendo alguns e empobrecendo outros. Com isso, constituiu-se uma nova paisagem agrícola, com o cultivo em larga escala de produtos destinados unicamente ao mercado de consumo. Para os que

\footnotetext{
1 Este artigo foi produzido com base em parte da dissertação de mestrado em História, intitulada "Envelhecer na cidade: memórias de mulheres aposentadas oriundas do espaço rural (Marechal Cândido Rondon)", desenvolvida junto ao Programa de Pós-Graduação em História da Universidade Estadual do Oeste do Paraná - UNIOESTE, na Linha de Pesquisa Práticas Culturais e Identidades.

${ }^{2}$ Sobre a ocupação do município, vide GREGORY, Valdir. Os eurobrasileiros e o espaço colonial: migrações no Oeste do Paraná (1940-70). Cascavel: EDUNIOESTE, 2002, p. 104.
} 
mantiveram suas atividades no campo, o cotidiano foi afetado por drásticas alterações no modo de viver e trabalhar. ${ }^{3}$

A instalação da usina hidrelétrica de Itaipu $^{4}$, no início dos anos 1980, e o consequente alagamento das terras que ladeavam o Rio Paraná provocaram mudanças no cenário fundiário da região, que levou à desapropriação das terras que seriam alagadas e à saída de muitos agricultores do campo em direção à cidade. Alguns dos que receberam indenização da Itaipu por suas propriedades usaram o dinheiro para comprar imóveis e viver na cidade; outros, muitos dos quais expropriados, mudaram-se da região.

As mulheres entrevistadas se mudaram para o espaço urbano por diferentes razões, além da desapropriação das terras, como problemas de saúde e facilidade de acesso a recursos médicos na cidade, maior oportunidade de estudo e trabalho para os filhos. A vinda para a cidade representava para os mais velhos o acesso a serviços, a recursos médicos e hospitalares e a serviços de assistência. A cidade também facilitava sua socialização com pessoas da mesma faixa etária, e com interesses semelhantes.

Nossa proposta, ao focalizar experiências e memórias de mulheres, procura articular as migrações e os deslocamentos campo/cidade com aquela perspectiva e também a questões voltadas à geração, já que se trata de mulheres idosas. Para a pesquisa, foram entrevistadas sete mulheres aposentadas. Destas, foram escolhidas narrativas orais de cinco delas, de acordo com sua trajetória, primeiro como migrantes oriundas do Sul e agricultoras, depois, como migrantes do campo à cidade.

Analisamos a forma como narram suas histórias de vida, os sentimentos, as emoções que surgem ao narrar e o que, diante das dificuldades enfrentadas, lembram

\footnotetext{
${ }^{3}$ A esse respeito, ver: FERRARI, Walter Junior. A expansão territorial urbana de Marechal Cândido Rondon PR: a produção da cidade a partir do campo. 2009. Dissertação de Mestrado em Geografia. Universidade Federal da Grande Dourados. Dourados/MS.

${ }^{4}$ Os estudos para a viabilidade da construção da usina hidrelétrica Itaipu binacional, uma parceria entre brasileiros e paraguaios, tiveram início em 1973. O ano da assinatura do Tratado de Itaipu, 1973, coincide com a eclosão da crise mundial provocada pelo aumento do preço do petróleo. Intensifica-se a exploração de fontes de energia renováveis como forma de assegurar um vigoroso desenvolvimento para o Brasil e o Paraguai. A construção da barragem teve início em 1974. O desvio do leito do Rio Paraná interferiu na vida de milhares de pessoas que habitavam às suas margens, atingindo uma faixa de 170 quilômetros, entre Guairá e Foz do Iguaçu. Em torno de 8.519 propriedades rurais e urbanas foram alagadas na margem brasileira e seus donos tiveram que ser indenizados. A obra gigantesca foi inaugurada em 5 de novembro de 1982. http://www.itaipu.gov.br/nossa-historia. Acessado em: 27 mar. 2013.
} 
e/ou preferem esquecer. Através da linguagem, nas entrevistas são narradas experiências vividas no passado, reelaboradas na narrativa no presente.

Apoiamo-nos nas considerações de Ecléa Bosi, que acredita que a arte da narração não esteja confinada nos livros. Para ela, o "veio épico é oral". Também acredita que "o narrador tira o que narra da própria experiência e a transforma em experiência dos que o escutam” (BOSI, 1994, p. 82).

Ao fazer uso da história oral, o historiador tem ampliado sobremaneira suas possibilidades de investigação e de interpretação. Uma delas é a própria questão da relação entre memória e esquecimento.

As falas das mulheres entrevistadas são cheias de expressões de saudade e nostalgia ao lembrar momentos passados que pareciam perdidos. Dentre eles, selecionaram os que deveriam ser lembrados, e os que, por ressentimentos, deveriam ser calados.

A partir da análise das entrevistas realizadas, procuramos relacionar suas falas a essas formas de conceber os/as idosos/as na sociedade contemporânea, mas também refletir sobre como elas se autorrepresentam.

As novas sociabilidades por elas construídas na cidade permitem pensar algumas questões que dizem respeito a práticas e discursos veiculados na esfera pública, que associam idosos ao direito de aproveitar a vida e usufruir de momentos de lazer.

Levando em conta este aspecto, em particular, este trabalho procura perceber como as mulheres em foco vivem a velhice na cidade e como significam o processo de envelhecimento. Junto com a conquista da aposentadoria, vem o envelhecimento, mas também vêm doenças, solidão e problemas de deslocamento. Entre a liberdade e o cerceamento, como é envelhecer na cidade? 


\section{Memórias (e esquecimentos) da vida no espaço rural}

Quando narraram suas histórias de vida, algumas se emocionaram ao recordar as diferentes fases de suas existências. As lembranças remontam a outros tempos e a outros lugares, além de a outras posições de gênero. São experiências vividas há muito tempo e que, ao virem à tona, despertam sentimentos e emoções. Elas lembram com carinho de diferentes fases, especialmente da época em que, casadas, viviam cercadas de filhos ainda crianças, pequenas.

Para dona Dora, 77 anos, viúva, mãe de oito filhos, as lembranças do passado são dolorosas. Trazem à memória sentimentos que a emocionam, conforme pode ser percebido quando ela diz: “Oh meu Deus... a gente se lembrá do passado não é bom, né?" (DORA, 2011). O momento passado que mais lhe desperta fortes emoções é o que a faz lembrar o marido doente. Para ela, agora viúva e morando sozinha, o período mais feliz foi aquele em que viveu cercada por seus familiares. Ela sente falta do marido e da convivência diária com os filhos. Por outro lado, quando perguntada sobre o que é bom lembrar, diz:

O que que era bom? Vamos dizer, os filhos bonitos que a gente tem, né e, o serviço que a gente conseguiu, né. Conseguimo ajudar tudo os filhos, né. A única coisa, né. Porque nós não saia quase, ia pra igreja e da igreja ia pra casa. Você pensa, com 8 filhos, né, não dava (DORA, 2011).

Ela e outras entrevistadas ressaltam ter podido ajudar os filhos. Suas lembranças do passado estão relacionadas ao trabalho e à vivência familiar. Em seu caso, com oito filhos, o que mais acentua é o cuidado com a família. Percebe-se, em sua fala, que o espaço de maior possibilidade de sociabilidades era a igreja, onde encontrava vizinhos e conhecidos. A privação, entretanto, parece recompensada, segundo sua narrativa, pelo futuro que pôde dar aos filhos.

Dona Olinda Camila, 82 anos, casada, mãe de sete filhos, cita o trabalho pesado na época da derrubada do mato, ao refletir sobre o que considera difícil de lembrar de seu 
passado. Embora não tenha ajudado a derrubar propriamente a mata, teve que ajudar o marido a serrar as toras de madeira e a tirar a lenha até o limite de suas forças:

Me admiro como nós não fiquemo manca das pernas, como nós passemo serrote nas toras assim, ele [marido] deixou muito pesado e eu já não... ele se judiava e eu não podia.

Entrevistadora: - A senhora ajudou a derrubar mato?

Dona Olinda: - Mato não, mas, sabe, depois quando derrubava e pra ajudar e pra tirar as lenha, sempre ajudava (OLINDA, 2011).

Dona Olinda considera "difícil” o tempo vivido na roça, de muito trabalho, embora, para ela, as conquistas alcançadas, como ter dado conta de todo trabalho e ter criado os filhos, tenham valido a pena. Para ela, as dificuldades devem ser esquecidas e as boas lembranças, prevalecer:

Como se diz, tem muitas coisas difíceis e tem muitas coisa que não é, é assim... Mas tem coisa difícil, como era de trabalhar, difícil quando já ta de idade, mas conseguiu. Como se diz... Antigamente, criança pequena, mas fiz todo o serviço. Como se diz, é difícil assim tu esquece também... Mas muitos não querem esquecer isso, mas tem que... $O$ que passou, passou, não volta mais e muitas coisas tem que aceitar (OLINDA, 2011).

Dona Irmélia, 72 anos, casada, mãe de quatro filhos, teve que pôr um fim ao sonho de seguir a carreira de professora. Diferentemente da maioria das mulheres da sua geração, ela teve oportunidade de estudar mais tempo que o usual entre as moças de sua região. Com o apoio dos pais, cursou a Escola Normal e chegou a lecionar por alguns anos enquanto morava no Rio Grande do Sul. Depois casou, mudou para uma localidade distante, onde teve de abrir mão do intuito de ser professora para ajudar o marido na colônia e cuidar dos filhos e da casa. Ela lamenta ao dizer: "Acabou o sonho. Fiquei na roça mesmo": 
O que eu me lembro mais da infância, é que eu sempre queria ser professora e daí eu consegui com meu pai, que ele falava: "Estuda, que é a coisa que ninguém pode tirar de um filho". É uma herança que um pai dá pra um filho que ninguém pode tirar, né.

E daí a gente conseguiu também, e daí a gente casou em 1960 e o sonho não ficou concretizado perfeitamente, porque lá eu não consegui a escola que ficava perto da minha casa, daí eu não ensinei no magistério, né, daí fui simplesmente uma agricultora pro resto da vida, né.

Ah, fiz o normal, em ljuí (RS) e lecionei 4 anos, que eu trabalhei no magistério, né. Daí, quando nós casamos, fomos morar em Guaraciaba (SC) e, a escola lá era bem pertinho de casa, eu não consegui essa escola, e daí eu não podia me deslocar pra um outro lugar, né, daí eu parei, né. $\mathrm{E}$ acabou ali. E acabou o sonho. Fiquei na roça mesmo e, daí as coisas não era assim fácil. Depois tinha os filhos e tinha que ajudar na lavoura, a casa e cuidar dos filhos tudo. Não é que nem hoje, hoje é tudo mais fácil, né (IRMÉLIA, 2011).

O fato de ter de "ficar na roça mesmo", de ter de "ajudar na lavoura" e, assim, ter de largar do sonho de ser professora a faz também marcar as diferenças entre os modos de trabalho e vida na agricultura no passado e na atualidade, em que "tudo é mais fácil".

O campo aparece como um lugar de muito trabalho e pobreza para as mulheres entrevistadas, muito embora ali tenham construído um patrimônio que valorizam e ali tenham criado seus filhos. Muitas foram as experiências vividas, muitas delas dolorosas, que agora preferem esquecer.

Nas memórias da maioria das mulheres entrevistadas, elas demonstram não sentir saudade da vida que levavam como trabalhadoras rurais. Para elas, o contraste entre a vida que vivem hoje na cidade e a que viveram na roça é grande. O espaço rural, antes habitado por elas, aparece como um lugar de muito trabalho e sacrifício. É muito distinto do campo pensado e representado como espaço bucólico e romântico pelos poetas e escritores ingleses do século XVI, investigados pelo historiador inglês Raymond Williams. Aqueles representavam o campo como local de refúgio e descanso, pois "o campo fresco no qual o poeta se refugia não é o do agricultor, e sim do morador desocupado" (WILLIAMS, 1989, p. 70).

Nas memórias de nossas entrevistadas não está presente a "recorrente evocação nostálgica de um passado rural de abundância e felicidade" (WILLIAMS, 1989, 
contracapa). Ao contrário, nelas se encontram elementos da dura realidade do trabalho braçal e constantes evocações do sacrifício. Assim, percebe-se que a vida rural tem significados diferentes para quem teve uma experiência direta e intensa no campo e para quem apenas observa a paisagem e o desenrolar da vida campestre.

Para dona Rení, 76 anos, casada, mãe de seis filhos, a vida trouxe mudanças no seu modo de viver e de se relacionar com as pessoas. Atualmente, como moradora da cidade, aposentada, ela considera que o tempo ruim já passou e agradece por todas as conquistas ao dizer: "Meu Deus do céu... Era... Mas graças a Deus que nós cheguemos nesse ponto. [...] E agora nós já temos 54 anos (de casados) e os filhos tudo..." (RENI, 2011) Para ela, resta agradecer e considerar este período de velhice como uma dádiva divina.

O filósofo Paul Ricoeur, que explora as ligações entre a experiência humana do tempo e a narrativa, entende que o "tempo do calendário" aproxima o tempo físico do tempo vivido. Portanto, a capacidade da memória pode ser determinada por uma vontade de ressignificação das coisas e de si mesmo, sendo possível uma reconfiguração de dados que, depois de guardados na memória, são despertados pela rememoração. Assim, na análise do autor, "não temos nada melhor que a memória para significar que algo aconteceu, ocorreu, se passou antes que declarássemos nos lembrar dela" (RICOEUR, 2007, p. 40).

Para o autor, duas abordagens dos fenômenos mnemômicos seriam possíveis, ou seja, o esquecimento por apagamento dos rastros, e a ideia de esquecimento reversível, o esquecimento de reserva. Então, os sentimentos, em relação ao esquecimento, seriam ambivalentes. De um lado, estaria o esquecimento profundo, da interiorização; de outro, o da retrospecção, a partir do reconhecimento da experiência. Segundo ele:

De um lado, o esquecimento nos amedronta. Não estamos condenados a esquecer tudo? De outro, saudamos como uma pequena felicidade o retorno de um fragmento de passado arrancado, como se diz, ao esquecimento. As duas leituras prosseguem no decorrer de nossa vida com a permissão do cérebro (RICOEUR, 2007, p. 427). 
Ao lembrar seu passado vivido na roça, fragmentos dele retornam à memória destas mulheres. Trabalhar na terra, cuidar dos interesses da casa, da alimentação e do bem-estar da família era responsabilidade das mulheres no meio rural. Cada uma delas, à sua maneira, contribui, com base em suas experiências e vivências no meio rural e por meio de seus relatos, a compor a sua história de vida. Uma história única, mas que traz elementos comuns a muitas mulheres. Cada uma com suas particularidades.

A conquista de uma vida mais confortável agora na velhice, ao ter suas casas com energia elétrica, chuveiro, torneira e máquina de lavar roupas é, para elas, um motivo de satisfação. Estas aquisições, que facilitam suas vidas, atualmente provocam um contentamento, considerado por elas como recompensa por todas as dificuldades vividas no passado. Elas acreditavam que todo o esforço da juventude seria recompensado com uma vida melhor na velhice. A ideia de uma recompensa, ou colheita, em muitos relatos, advém de uma interpretação também calcada na religiosidade de muitas delas. Elas estavam lançando a semente na terra para poder colher os frutos no futuro, pois, como está escrito, "no tempo próprio colheremos, se não desanimarmos" 5.

\section{“[...] mas eu tô fazendo a minha parte”: velhice e escrita de si}

Na narrativa oral de dona Irmélia, a experiência aflora na escrita de um diário pessoal. Ela procura, através da escrita de um diário, não deixar cair no esquecimento atividades e acontecimentos que considera importante preservar.

Ao narrar às gerações futuras as lembranças sobre a sua vida, ela afirma: "[...] mas eu tô fazendo a minha parte" (IRMÉLIA, 2011). Diferentemente das outras mulheres entrevistadas para este trabalho, é a única que teve oportunidade de concluir o antigo "segundo grau", atual ensino médio. Assim ela descreve seu ponto de vista acerca da importância da prática da escrita de si:

\footnotetext{
${ }^{5}$ Bíblia Sagrada, 2000, p. 935.
} 
E aconteceu um fato muito importante, eu gosto muito de fazer o meu diário, daí eu tava sentada no consultório, fazendo, escrevendo assim, daí um "tio" olhou pra mim e falou: "A senhora tá escrevendo o seu diário?", "Sim" eu falei, daí ele disse: "A senhora acha que daqui 20 anos alguém vai ler isso?". Daí eu pensei um pouco e fiquei assim: "Ué, o que que ele quer dizer?", daí eu falei: "Não, se alguém vai ler, ou não vai ler, isso eu não sei, não vou viver isso pra saber se daqui 20 anos alguém vai ler, mas eu tô fazendo a minha parte. Se algum bisneto quiser saber da vida da avó, ou da bisa, se ninguém tiver tempo pra sentar e conversar com ele [risos], pega o meu diário e olha, daí ele vai saber a vida da bisa [risos], não é verdade? Então você vai fazendo um diário, tem dias que... Lá tem... Que não tem nada, né. Então você imagina, depois quando vai ler, você imagina. Ou tava viajando e não deu tempo pra escrever, ou não tava disposta, ou tava muito bem disposta, demais e não quis escrever nada, quis fazer outras coisas [risos], ou tava doente, daí aquela parte branca, você imagina o que você quiser, então... O meu marido não gosta disso, mas eu gosto (IRMÉLIA, 2011).

Apesar disso, para ela é importante expressar seus sentimentos e suas emoções, sem se incomodar com a opinião alheia. A sensibilidade da entrevistada em registrar suas memórias em um diário é percebida como algo inútil e desnecessário por parte destes dois homens. Grande parte deles, dos de sua geração, criados para serem fortes, corajosos e racionais, consideram isso "coisa de mulher". A entrevistada, ao citar ambos os homens, afirma, com segurança, a importância daquela prática de escrita de si.

O psicanalista italiano Contardo Calligaris entende que o sujeito que escreve sobre sua vida, o escrito autobiográfico, está se produzindo como pessoa através daquilo que escreve. O autor lembra que sempre se escreveram histórias e que a própria "vida é uma história". Esta passou a ser objeto da análise histórica com base em diferentes fontes históricas, entre as quais, diários, biografias, histórias de vida, documentos, correspondências, que guardam as evidências do que foi vivido e sentido individualmente. Os romances seriam também inspirados em histórias reais. O autor entende, assim:

[...] que a autobiografia (escrita ou simplesmente vivida) e mesmo o diário não param de buscar no repertório do erfarhungen narrativas que o romance vem acumulando e generosamente oferecendo como patrimônio de todos. Vivemos nossas vidas como romance e, 
reciprocamente, encontramos na literatura modelos para nossas vidas (CALLIGARIS, 1997, p. 91).

Ao querer que sua narrativa de si seja lida depois (e talvez até publicada), dona Irmélia parece também querer fazer do leitor a sua experiência. A associação dos seus escritos com o roteiro de uma novela é o molde que ela tem para o sentido de si. Ela segue sua narrativa dizendo que fica imaginando qual seria a reação de algum dos netos ou possíveis bisnetos ao ler seus escritos no futuro. Seu sonho é ver tudo publicado em um livro. Assim ela se expressa:

Entrevistada: É, eu sempre quis escrever um livro, daí eu começava... Eu acho que eu tenho uns 4, 5 cadernos que eu começava a escrever, daí eu guardava, daí eu comprava um caderno novo, daí eu pensava: "Vou fazer tudo de novo", mas daí de novo começava, mas não terminava.

Entrevistadora: Mas tem que terminar...

Entrevistada: Ah, mas daí eu penso, um dia alguém vai juntar tudo e vai fazer isso, quando a gente não tiver mais aqui, se alguém não tiver o que fazer [risos] (IRMÉLIA, 2011).

Esse "arquivamento do eu”, em forma de diário, escrito por dona Irmélia, no qual foram selecionados alguns elementos da vida considerados importantes, tem a função de fazer refletir sobre a própria vida, entender um pouco melhor a si mesmo. Segundo o historiador francês Philippe Artières: “Arquivar a própria vida é se pôr no espelho, é contrapor à imagem social a imagem íntima de si próprio, e nesse sentido o arquivamento do eu é uma prática de construção de si e de resistência" (ARTIÈRES, 1998, p.11).

Dona Irmélia espera deixar o diário como um legado a seus descendentes e, dessa forma, não deixar morrer com ela a história de sua vida. É uma maneira de resistir ao tempo. Enfim, é ver sua identidade reconhecida e preservada ao chegar a um futuro leitor. Neste sentido, Philippe Artières afirma: 
Sempre arquivamos as nossas vidas em função de um futuro leitor autorizado ou não (nós mesmos, nossa família, nossos amigos ou ainda nossos colegas). Prática íntima, o arquivamento do eu muitas vezes tem uma função pública. Pois arquivar a própria vida é definitivamente uma maneira de publicar a própria vida, é escrever o livro da própria vida que sobreviverá ao tempo e à morte (ARTIÈRES, 1998, p. 32).

Dona Irmélia, em sua narrativa, segue dizendo que tudo o que tem escrito durante estes anos são registros de fatos e acontecimentos baseados na vida real que pretende transmitir às gerações posteriores de sua família. Deixou-me muito feliz ao dizer: “É, quem sabe um dia você não vai ser a primeira a ler o diário, que o homem achou que ninguém ia ler" (IRMÉLIA, 2011). Esta afirmação remete não somente a um sentimento de confiança e identificação com a entrevistadora, também mulher e conhecida, como também, e explicitamente, à diferença que estabeleceu em relação ao homem citado.

A entrevistada, em sua narrativa, afirma registrar apenas os fatos, considerando ser impossível descrever também seus sentimentos e as emoções do vivido:

Então, porque eu sempre penso assim, se eu tivesse escrito todos os dias, né, só o mínimo assim, né, e mandasse ajeitar essas escritas, o livro tava pronto e o roteiro de novela também. Eu sempre avisava os meus filhos, que eu quero fazer uma herança pra eles, que eles possam depois vender o roteiro da vida da avó [risos] pra fazer uma novela, daí quem sabe, eles não têm a herança. Porque as novelas não eram...

Entrevistadora: Baseados na vida real.

Entrevistada: Na vida das pessoas, por isso que dá pra deixar registrado.

Entrevistadora: E sempre alguém se interessa.

Entrevistada: Se observa as novelas profundamente, sempre da vida de alguém... e ele [autor] tira isso de algum lugar, porque...

Entrevistadora: Ninguém imagina tudo, né.

Entrevistada: Ninguém pode, pelo menos eu não consigo imaginar tanta coisa, eu escrevo o que eu vi, nem tudo, tudo, tudo não vai. Os sentimentos, as emoções. Interessante isso (IRMÉLIA, 2011).

Suas anotações sobre acontecimentos de sua vida podem ser entendidas como uma arte da narrativa. Walter Benjamin, filósofo e escritor, analisou essa arte em 0 
Narrador, acreditando que o que é narrado por ele é incorporado à experiência do ouvinte: "O narrador retira da experiência o que ele conta: sua própria experiência ou a relatada pelos outros. E incorpora as coisas narradas à experiência dos seus ouvintes" (BENJAMIN, 1985, p.201).

O autor segue afirmando que "as experiências estão deixando de ser comunicáveis" (BENJAMIN, 1985, p. 200) devido ao isolamento em que vivem as pessoas na sociedade moderna e à predominância das informações jornalísticas que circulam rapidamente e enfatizam as transformações que ocorrem na sociedade capitalista. Porém, para ele, "a experiência que passa de pessoa a pessoa é a fonte a que recorreram todos os narradores. E, entre as narrativas escritas, as melhores são as que menos se distinguem das histórias orais contadas pelos inúmeros narradores anônimos" (BENJAMIN, 1985, p.198).

A filósofa Jeanne-Marie Gagnebin, ao interpretar a vida e a obra de Walter Benjamin, destaca que, para este autor, a narração seria "a arte de contar, sem a preocupação de ter de explicar tudo; a arte de reservar aos acontecimentos sua força secreta, de não encerrá-los numa única versão” (GAGNEBIN, 1993, p.59). Ou seja, ao retransmitir sua experiência, Benjamin considera que "o relato do narrador permanece irredutível a interpretações posteriores, capaz, por isso mesmo, de provocar surpresa e reflexão mesmo depois de muitos séculos" (GAGNEBIN, 1993, p. 59-61).

É o que pretende também dona Irmélia com sua narrativa. Ela conta que sempre gostou de escrever e começou a tomar gosto pela escrita depois de ter sido elogiada por uma cunhada, do Rio Grande do Sul, com quem se correspondia habitualmente. Assim ela conta como era sua forma de contato com os familiares daquele estado:

Mas eu sempre gostei de escrever, sabe, de xeretar principalmente, porque eu tenho uma cunhada, em ljuí, ela é diferente da gente, assim, ela parece uma moça tímida... Uma coisa assim, ela é diferente, mas muito querida. Então ela sempre me elogiava, que ela gostava. Que antigamente, você não telefonava, você escrevia uma cartinha, recebia um bilhetinho, quando uma visita vinha trazia um recado, né, era a comunicação. Então eu sempre escrevia pra minha família, escrevia pro 
meu pai, minha mãe e pra toda a minha família, escrevia assim pra eles e todo mundo ia lá ler, sabe (IRMÉLIA, 2011).

Podemos observar que para dona Irmélia a carta não era apenas uma forma de comunicação com a família, mas também uma forma de incentivar a cunhada, segundo ela, uma moça tímida, a participar de maneira mais ativa do convívio familiar.

Neste sentido, destacamos as considerações da historiadora Teresa Malatian, para quem os escritos autobiográficos seriam atividades de introspecção, nas quais "o indivíduo assume uma posição reflexiva em relação à sua história e ao mundo onde se movimenta' (2011, p. 195). E as cartas seriam uma maneira de "refletir e falar sobre si" (MALATIAN, 2011, p. 196). Ao ser trocadas, estas, além das informações contidas, expressavam os sentimentos e as emoções da pessoa que as enviava a seu destinatário. Sobre isso ela afirma:

Não raro, as informações eram acrescidas de fotos, recortes de jornais, flores secas, mechas de cabelos e outros objetos de memorabilia, fragmentos do vivido materializados e ofertados em relicário ao correspondente (MALATIAN, 2011, p. 200).

Teresa Malatian considera que, com o avanço da tecnologia, as cartas perderam espaço para novas formas de comunicação e informação. O que também pode ser constatado quando dona Irmélia, ao ser perguntada sobre seu relacionamento com os filhos e netos, destaca a importância atual do telefone celular para manter um contato constante com os familiares distantes. Ela compara o tempo passado, em que as pessoas se comunicavam através de cartas, com o tempo presente em que, diferentemente, as pessoas se comunicam através do telefone. Ela tem duas filhas que moram nas proximidades de sua casa e convive com elas e os netos diariamente. O único filho homem mora no Rio Grande do Sul e ela pouco o vê, além de um neto que mora no Mato Grosso, com o qual se comunica também através de "cartinhas", que gosta de escrever. Assim ela narra: 
Entrevistadora: Mas vocês se falam sempre?

Entrevistada: Sempre, sempre assim. Agora com esse negócio de celular tá tudo mais fácil, antigamente nós se comunicava menos, né, mas agora com esses celular... Antigamente eu fazia cartinha, eu gosto muito de escrever cartinha. [...] As vezes eu ainda faço, eu tenho um neto que mora no Mato Grosso, pra ele eu escrevo, porque ele tem 10 aninhos, e daí a gente fala no telefone, mas ele vai embora ali do telefone e esquece, e já não lembra mais o que a vó falou, né, então se ele tem a cartinha, ele pode no outro dia, senta lá e olhar quando ele lembra da vó de novo, ele pode dizer: "Ah, a vó não escreveu mais, então eu vou olhar a carta velha". Então eu acho assim, bem...

Entrevistadora: E ele escreve pra senhora também?

Entrevistada: Ele escreve, mas como lá as escolas não são mais assim, pra frente, né, então ele não tem aquela coisa pra frente, um... Pela idade que ele tem, ele podia ta mais adiantado, mas ele escreve, ele liga. Ele sempre quer vir aqui, mas é tudo muito difícil, né, tanto pra ele, quanto pra nós, se nós tivesse condições, pagava passagem pra ele e pra mais uma pessoa, porque ele não pode viajar sozinho e a mãe dele trabalha, então é mais complicado, né. Mas ele liga, a gente liga pra ele, mas eu escrevo as cartinhas, daí pra ver o que que dá isso. A noção da cara dele (risos). Por isso que eu digo, se eu falo no telefone, ele esquece logo, né, assim se ele vai ler a cartinha, não, ele vai lembrar: "Opa, olha ali o que a vó escreveu". (IRMÉLIA, 2011).

Dona Irmélia, como avó, ao escrever as "cartinhas" para o neto e esperar que ele as guarde como uma lembrança dela, pode ser considerada uma mediadora entre as gerações passadas e futuras de sua família. A carta é, para ela, também uma forma de exercer o seu papel de professora com o neto. Ela se preocupa com a educação dele: o uso da antiga forma de comunicação a distância (a carta) para manter um vínculo com uma nova geração (o neto), apesar do celular. A preocupação de que o neto não esqueça o que disse e a valorização da cultura escrita, em detrimento da oral, é algo muito importante para ela e que podemos associar à sua profissão de professora.

Para a antropóloga Myriam Moraes Lins de Barros, as mulheres da família, especialmente as avós, assim como dona Irmélia, ao guardar lembranças familiares como fotografias, diários e objetos passados de uma geração a outra exerceriam o papel de guardiãs da memória familiar, além de estabelecerem a ligação entre o passado vivido e as lembranças das gerações futuras. A autora entende que os avós são "apresentados como elo vivo entre gerações, os mediadores que transmitem a história de um passado 
vivido e experimentado" (BARROS, 1989, p. 33). A autora considera que a transmissão dos chamados bens simbólicos, como móveis e objetos familiares, diários e fotografias, "não são apenas partes de um passado, mas símbolos da família, dos laços e descendência, que podem ser transcritos como bens que contêm uma história" (BARROS, 1989, p. 35). Assim, ao preservar e transmitir as memórias do que viveu e sentiu através das anotações de seu diário, dona Irmélia representa "a união entre seus antepassados e seus descendentes" (BARROS, 1989, p. 33).

\section{"Velhice e família"}

Para muitos idosos, assim como para dona Irmélia, a velhice é um tempo de nostalgia, em que afloram as lembranças de tudo o que foi vivido em épocas passadas. Apesar das inúmeras conquistas e da participação dos idosos em diferentes atividades no âmbito social, ainda prevalecem, nas mulheres entrevistadas, as lembranças de encontros e de comemorações familiares. Seria a velhice um tempo de curtir a família? Ou seriam as lembranças de um passado cheio de dificuldades e muito trabalho um incentivo para aproveitar cada oportunidade que a vida lhes oferece?

A família sempre foi a principal referência na vida destas mulheres. Embora elas considerem importante e valorizem o aspecto afetivo presente no grupo familiar, a sua existência já deixou de significar uma vida restrita ao lar. Percebemos, através de suas narrativas orais, que o que mais querem, e precisam, durante o processo de envelhecimento, é viver em um ambiente em que recebam amor, carinho, atenção e respeito, não só dos membros da família, mas de toda a sociedade.

Simone de Beauvoir, em seu livro sobre o processo de envelhecimento, criticou a atitude da sociedade para com os velhos. Ela declara que:

Homem algum deveria chegar ao fim da vida solitário de mãos vazias. Se a cultura não fosse um saber inerte, adquirido de uma vez por todas para ser, logo em seguida, esquecido, se fosse, pelo contrário, prática e viva, e se o indivíduo com seu auxílio pudesse agir sobre seu ambiente, de uma maneira que se iria realizando e renovando no decorrer dos anos, ele poderia ser em todas as idades, um cidadão ativo e útil (BEAUVOIR, 1970, p. 302). 
A sensação de pertencer, fazer parte de um grupo, tanto em atividades públicas quanto privadas, como as reuniões familiares, é extremamente salutar. Através de suas narrativas, a maior parte das entrevistadas revelou ter boa integração com seus familiares e contatos frequentes com os mais próximos. Estar em companhia dos filhos e netos adquire um valor especial na velhice. É o que se percebe quando dona Maria Adélia lembra a alegria que sentiu quando viajou com a família, em ônibus contratado, para o Rio Grande do Sul, para participar de uma festa da família. Apesar de ter ficado sentada com os pés levantados, por conta de uma trombose, ela se sentiu feliz e confortável porque, durante a viagem, havia música e dança no espaço limitado do ônibus para alegrar a todos. Quando perguntada se gosta de viajar, ela respondeu:

Eu? Gosto, eu gosto. E olha, agora quando nós fomos pra Rio Grande, nós viajemos com ônibus de 2 andares, que nem se nos sentava na cama, eu tinha na frente 4 colchão, na minha frente no banco, 4 colchão e mais ainda uma cesta e um travesseiro e, daí eu tinha o pé em cima deitado e, quando eu cheguei em casa eu nem sentia mais nada com minha trombose, nada. Que ótimo, que legal, né. É tanto tempo, né, tantas horas o pé erguido, né. E todo o mundo, ninguém, ninguém ficou triste ou ninguém não ficou mal, nos tinha de noite um disco na frente no ônibus, ele tocava, minha gente do céu, até as mulher se levantava e dançava dentro do ônibus. Olha, foi tão feliz, tão feliz, tão feliz, aí a volta, muito feliz (MARIA ADÉLIA, 2011).

É perceptível, na sua narrativa, a alegria que ela sentiu ao viajar com a família e ver todos se divertindo, pois compartilhar atividades ajuda a manter os laços afetivos com os demais membros da família. Este sentimento de pertencimento a todo um grupo familiar fez com que os incômodos da viagem fossem esquecidos e as boas lembranças destes momentos ficassem registradas em sua memória. Ela se alegra com a expectativa de uma nova viagem para Santa Catarina, com toda a família, para o casamento de um dos netos:

Entrevistada: E agora nós vamos fazer, o mês que vem, uma viagem de novo pra Santa Catarina, e a Maria [filha] tem o casamento do seu filho 
Diego, né e vai o mesmo ônibus que levou agora nós e vai tudo nós de novo.

Entrevistadora: Vai toda a família?

Entrevistada: Aham vai os amigos, os amigos e as amigas, é, vai ser muito legal. [...] Com essa idade muita gente, muita gente falava: "Paulo (filho), sei lá, porque teus pais com essa idade gostava de viajar". O Paulo disse que essa não foi a última vez. Eu também acho.

Entrevistadora: É tão bom, né?

Entrevistada: É. Deus me livre! Olha, o que que a gente querem mais, né? O que que tu gosta mais de fazer, do que ver a tua cidade né, onde tu nasceu, onde tu cresceu, foi no dentista e tudo, né. Olha isso é tão legal, ninguém não sabe como, é muito, muito, muito legal (MARIA ADÉLIA, 2011).

Dona Maria Adélia se emociona ao mencionar a viagem ao lugar em que viveu sua infância em companhia de seus familiares. Para ela, foi uma experiência indescritível. Assim como também foi a festa que os filhos prepararam para comemorar suas bodas de ouro. Ela guarda com carinho o álbum com as fotografias em que aparecem alguns de seus familiares já falecidos. Ao ser perguntada sobre as boas lembranças de sua vida, assim se referiu a este momento:

Ah, isso eu tenho que ir buscar o meu álbum que eu casei com (há) 50 anos, ai tu pode ver alguma coisa. Deus me livre... E a filha queria fazer pro ano que vem de novo, eu falei que eu não quero, mas eles querem fazer (MARIA ADÉLIA, 2011).

Lembranças de encontros familiares são importantes na vida destas mulheres. Os álbuns de fotografias, guardados com carinho, e os porta-retratos, espalhados pelos móveis, revelam este aspecto.

Na memória de dona Rení também ficaram registradas as lembranças das comemorações de datas festivas, como aniversários, dia das mães e dia dos pais. Na estante de sua sala estão presentes as fotografias que retratam estas comemorações. $O$ convívio com filhos e netos, que fazem parte do seu cotidiano familiar, assim como o fato 
de que, segundo ela, todos "são muito bom pra nós", é importante nesta fase de sua vida. Conforme sua narrativa:

Entrevistada: E agora nós já temos 54 anos (de casados) e os filhos tudo...

Entrevistadora: Os filhos moram aqui perto?

Entrevistada: Não, 2 moram em Toledo, 1 mora em Nova Mutum, Mato Grosso e o filho mora em Iguiporã e 2 filhas moram aqui.

Entrevistadora: Vocês se vêem então seguido? Se visitam?

Entrevistada: Sim, sim, nossa, nossa!!! Ih... E se tu vê, olha... O filho, ele não podia vim, domingo, Dia dos Pais, ele tinha festa lá em Iguiporã, ele tinha que ajudar na festa. E dali ele me ligou no rádio (telefone), pra mim ontem. Deu "meus parabéns" pra mim. E daí a filha que mora ali, o marido dela, ele é bombeiro e ele tinha que trabalhar domingo, mas e daí domingo de noite, ela tem 3 menina, tem gêmeas, e daí ela, as meninas e os namorado vieram aqui. $\mathrm{E}$ a filha que mora aqui, a Noeli, também tavam aqui de noite. E de dia nós tava na casa da filha, da Noeli. Porque ele também tem os 2 filhos casados eles também queriam vim em casa, lá no pai e nós daí. E segunda, daí as 2 filhas de Toledo vieram pra cá, porque domingo elas também tinha Dia dos Pais em casa. Daí eles chegaram aqui. Mas, olha... Os filhos são 100\% pra nós. Deus me livre!! Eles não sabe o que que eles é pra você. Ele (marido) falou nos temos que manda fazer mais guarda roupa. Tanta coisa eles compram pra nós. Meu... Ele sempre já fala: "Pra quê, pra quê? Nós já temo demais." Mas, temo de aceitar, né. São muito bom pra nós (RENI, 2011).

O tempo de velhice é para mulheres, como dona Reni, dona Irmélia e também para dona Maria Adélia, junto com seus respectivos maridos, um tempo de curtir a família. Por suas narrativas, elas destacam a importância de usufruir deste tempo precioso com os familiares. Tempo com o qual todos os seres humanos deveriam também poder contar no final de sua existência.

Percebemos, nas narrativas das mulheres entrevistadas, que elas relacionam fatos de suas vidas com datas e acontecimentos familiares. Permanecem vivas em suas memórias as lembranças boas de festas e comemorações, legando ao esquecimento as lembranças de acontecimentos traumáticos e negativos. A esse respeito, o filósofo Paul Ricoer lembra: 
[...] o esquecimento reveste-se de uma significação positiva na medida em que o tendo-sido prevalece sobre o não mais ser na significação vinculada à idéia do passado. $O$ tendo-sido faz do esquecimento o recurso imemorial oferecido ao trabalho da lembrança (RICOEUR, 2007, p.451).

O filósofo segue sua reflexão a respeito do esquecimento, afirmando:

[...] o esquecimento de impressões e de acontecimentos vivenciados (isto é, de coisas que sabemos ou que sabíamos) e o esquecimento de projetos, que equivale à omissão, à negligência seletiva, revelam um lado ardiloso do inconsciente colocado em postura defensiva (RICOEUR, 2007, p. 454).

Portanto, para o autor, “[...] antes do abuso, há o uso, a saber, o caráter inelutavelmente seletivo da narrativa. Assim como é impossível lembrar-se de tudo, é impossível narrar tudo" (RICOEUR, 2007, p.455).

Neste sentido, de não ser possível lembrar tudo, e de que a memória seleciona aquilo que deve ser lembrado e aquilo que deve ser deixado ao esquecimento, perguntamos se o esquecimento não seria um recurso, usado pela memória destas mulheres para selecionar apenas os aspectos positivos do passado vivido por elas!

\section{Considerações finais}

A produção deste trabalho foi baseada em narrativas orais de mulheres idosas, que, ao expor suas trajetórias de vida, trouxeram ao presente lembranças de vivências e experiências passadas. Em busca de uma compreensão a respeito de suas experiências, inicialmente como jovens mulheres migrantes, mães de família e, agora, senhoras aposentadas, ouvimos aquilo que elas se dispuseram a contar. 
Suas narrativas abrangem diferentes aspectos de suas vidas, desde o trabalho na roça até a falta de recursos, especialmente financeiros, a criação dos filhos, a migração para o espaço urbano e a posterior aposentadoria. Elas vêm acompanhadas de emoções geradas pelas lembranças das experiências cotidianas que tiveram no decorrer de sua história.

Ao narrar suas experiências e vivências, as mulheres entrevistadas englobam toda a família, uma vez que seus maridos, filhos e netos fazem parte do seu universo cotidiano.

Ao trazer o recorte de gênero para pensar estas experiências, percebemos os significados e as práticas femininas presentes em suas trajetórias de mulheres imigrantes, que também ajudaram a construir a cidade e o campo, embora invisibilizadas em muitas narrativas da história da cidade. A história local é contada por memorialistas com base no discurso do pioneirismo, como em outras cidades do oeste do Paraná, sempre evidenciando o trabalho realizado pelos homens. Consideramos, contudo, que o gênero atravessa a experiência de homens e mulheres e expressa relações de poder e hierarquias (SCOTT, 1998, 301). Portanto, há que se tratar de posições e de atributos de gênero, que são construções sociais de um dado momento histórico.

Ao ouvir as histórias de vida de mulheres e focalizar suas memórias, não estamos simplesmente contando a "história das mulheres", mas buscando trazê-las enquanto sujeitos históricos e entender as relações sociais no interior das quais viveram.

A realização de entrevistas de histórias de vida, neste trabalho, revelou-se um processo enriquecedor, também em razão da troca de experiências entre entrevistadora e entrevistadas. As narrativas nos revelaram não só as experiências vividas, mas também os sentimentos, as expectativas e os sonhos que estiveram e continuam presentes em suas vidas e nas de suas famílias. Expor estas experiências se mostrou um importante desafio para todos os envolvidos na pesquisa.

Acerca de memórias de velhos, a psicóloga social Ecléa Bosi descreve a importância de ouvir as experiências de quem viveu e trabalhou em outras épocas. Em seu entender: 
Um mundo social que possui uma riqueza e uma diversidade que não conhecemos pode chegar-nos pela memória dos velhos. Momentos desse mundo perdido podem ser compreendidos por quem não os viveu e até humanizar o presente. A conversa evocativa de um velho é sempre uma experiência profunda repassada de nostalgia, revolta, resignação pelo desfiguramento das paisagens caras, pela desaparição de entes amados, é semelhante a uma obra de arte (BOSI, 1994, p. 82).

A análise das histórias de vida dessas mulheres procurou valorizar não só os aspectos sociais e históricos, como também os aspectos emocionais e individuais presentes em cada narrativa oral. A análise das práticas cotidianas desenvolvidas por estas mulheres e seus maridos, filhos e familiares, e das representações que elas fazem de suas experiências, terão como função a construção de novos significados para conceitos como idade e velhice, e a forma como elas interagem com o mundo ao seu redor durante o processo de envelhecimento.

\section{Referências}

ARTIÈRES, Philippe. Arquivar a própria vida. In: Estudos Históricos. Rio de Janeiro, v. 11, n. 21, 1998. p. 9-34.

BARROS, Myriam Moraes Lins de. Memória e Família. In: Estudos Históricos. Rio de Janeiro. v. 2, n. 3, 1989. p. 29-42.

BEAUVOIR, Simone de. A Velhice. Difusão Européia do Livro. São Paulo, 1970.

BENJAMIN, Walter. O narrador. Considerações sobre a obra de Nikolai Leskov. In: Magia e técnica, arte e política. Ensaios sobre literatura e história da cultura. Obras Escolhidas, v. I. São Paulo: Brasiliense, 1985. p. 197-221.

BOSI, Ecléa. Memória e sociedade: lembrança dos velhos. 3. ed. São Paulo: Companhia das Letras, 1994.

CALLIGARIS, Contardo. Verdades de autobiografias e diários íntimos. In: Estudos Históricos. Rio de Janeiro, v. 10, n. 19, 1997. p. 83-97. 
FERRARI, Walter Junior. A expansão territorial urbana de Marechal Cândido Rondon - PR: a produção da cidade a partir do campo. 2009. Dissertação ( Mestrado em Geografia) Universidade Federal da Grande Dourados, Dourados/ MS.

GAGNEBIN, Jeanne-Marie. Walter Benjamin. Os cacos da história. 2. edição. São Paulo: Brasiliense, 1993.

GREGORY, Valdir. Os eurobrasileiros e o espaço colonial: migrações no Oeste do Paraná (1940-70). Cascavel: EDUNIOESTE, 2002.

HOERLLE, Gladis. Envelhecer na cidade: memórias de mulheres aposentadas oriundas do espaço rural (Marechal Cândido Rondon). 2013. Dissertação (Mestrado em História) Universidade Estadual do Oeste do Paraná, Campus de Marechal Cândido Rondon.

MALATIAN, Teresa. Narrador, registro e arquivo. In: Carla Bassanezi Pinsky e Tânia Regina de Luca (Org.). O Historiador e suas fontes. São Paulo: Contexto, 2011. p. 195-221.

RICOEUR, Paul. A memória, a história e o esquecimento. Campinas, SP: Editora da UNICAMP, 2007.

SCOTT, Joan W. A invisibilidade da experiência. In: Projeto História. São Paulo, n. 16, 1998. p. 297-325.

WILLIAMS, Raymond. O campo e a cidade: na história e na literatura. São Paulo: Companhia das Letras, 1989.

\section{Fontes orais}

Dora Kolm, 77 anos. Entrevista realizada pela autora em 8 ago. 2011. Marechal Cândido Rondon.

Irmélia Drews Schmitt, 72 anos. Entrevista realizada pela autora em 8 out. 2011. Marechal Cândido Rondon.

Maria Adélia Lerner Griebeler, 79 anos. Entrevista realizada pela autora em 13 set. 2011. Marechal Cândido Rondon.

Olinda Camila Wittech, 82 anos. Entrevista realizada pela autora em 26 ago. 2011. Marechal Cândido Rondon.

Rení Riffel, 76 anos. Entrevista realizada pela autora em 17 ago. 2011. Marechal Cândido Rondon. 
Recebido em: 20/02/2014 Aprovado em: 07/05/2014

Universidade do Estado de Santa Catarina - UDESC Centro de Ciências Humanas e da Educação - FAED Revista PerCursos Volume 15 - Número 28 - Ano 2014 revistapercursos@gmail.com 